Marta Rodziewicz

Uniwersytet Łódzki

\title{
Geneza zmian systemowych na Węgrzech po 1989 r.
}

Podejmując problematykę transformacji ustrojowej na Węgrzech, należy wskazać na determinanty przemian polityczno-społecznych zachodzących tu po II wojnie światowej. Rozpoczęty w 1989 roku proces demokratyzacji nawiązywał bowiem zarówno do powstania z 1956 roku, jak i wydarzeń i skutków epoki J. Kádára.

Wydarzenia z lat 1956-1989, w szczególności reformy Kadara, miały niepodważalny wpływ na przebieg transformacji, jak również na kształtowanie tożsamości narodowej węgierskiego społeczeństwa. Stanowią one element charakterystyczny oraz wyróżniający Węgierską Republikę Ludową na tle pozostałych państw bloku wschodniego ${ }^{1}$.

Wpływy radzieckie na Węgrzech pojawiły się tuż po drugiej wojnie światowej. Na węgierskiej scenie politycznej brak było głęboko zakorzenionych tradycji demokratycz-

\footnotetext{
1 Powyższa praca stanowi fragment pracy magisterskiej „Drogi wychodzenia z komunizmu. Analiza porównawcza transformacji systemowej w Polsce i na Węgrzech w oparciu o wybrane determinanty wewnętrzne".
} 
nych ${ }^{2}$. Wzrastało znaczenie komunistów, dla których poparcie deklarowało 20\% węgierskiego społeczeństwa. Wykorzystując sprzyjającą sytuację, Związek Radziecki przypieczętował swoje wpływy podczas wyborów 31 sierpnia 1947 roku, w których komuniści zdobyli pełną władzę. Delegalizacji uległy partie opozycyjne, czyniąc z partii komunistycznej jedyną funkcjonującą na arenie politycznej. Kolejnym krokiem było wprowadzenie w 1949 roku nowej konstytucji, zmieniającej nazwę państwa na Węgierską Republikę Ludową oraz wprowadzającej system komunistyczny, na wzór tego panującego w Związku Radzieckim³.

Najbardziej zbliżony do radzieckiego pierwowzoru był właśnie stalinizm węgierski. Formy i mechanizmy wprowadzania systemu, stosowane w latach 1949-1956 przez Matyasa Rakosiego, przewyższały swoją brutalnością metody stosowane w pozostałych państwach bloku wschodniego ${ }^{4}$. Ter-

2 Węgry, przegrywając dwie wojny światowe, z państwa będącego częścią Monarchii Habsburgów, stały się podmiotem politycznym pozbawionym de facto suwerenności. Dyktatura Miklosa Horthyego zakończyła się w 1945 roku, przerywając niedemokratyczne rządy na zaledwie 2 lata, kiedy to wybory 1945 roku wygrała prozachodnia Niezależna Partia Drobnych Rolników.

3 M. Migalski (red.), Partie i systemy partyjne Europy Środkowej i Wschodniej, Sosnowiec 2005, s. 55.

${ }^{4}$ E. Czarkowska, Interwencja Zwiq̨zku Radzieckiego na Węgrzech w 1956 roku, Toruń 2006, s. 46. Współpracownicy Rakosiego stworzyli własny system ucisku społeczeństwa, dopuszczając się zbrodni i powodując straty wśród ludności. Wprowadzono również mechanizmy uniemożliwiające działalność grup innych niż komunistyczne, dlatego też początkowo w Węgierskiej Republice Ludowej, w latach 1949-1956 brak było jakiejkolwiek opozycji antykomunistycznej. Istniał za to konflikt wewnętrzny między aktywistami komunistycznymi, działającymi podczas 
ror stał się impulsem do wybuchu rewolucji w 1956 r.5 Wtedy też ujawniła się opozycja wobec władz komunistycznych. Rewolucji towarzyszyło bowiem pojawienie się, na krótko, na węgierskiej scenie politycznej partii opozycyjnych. Mimo iż wojska radzieckie szybko stłumiły działania opozycji, tak samo jak po dwóch tygodniach krwawo stłumiły powstanie, to wydarzenia roku 1956 miały swoje konsekwencje zarówno dla Węgrów jak i innych państw bloku wschodniego ${ }^{6}$.

Władza zdecydowała się na podjęcie reform, w szczególności liberalizacji polityki wewnętrznej i poprawy stopy życiowej. W zamian domagała się jednak zaniechania podejmowania protestów i działań skierowanych przeciw partii rządzącej. Realizatorem tej polityki stał się János Kádár, sekretarz generalny KC węgierskiej partii komunistycznej, który przeprowadził poważne reformy gospodarcze w latach 60 .

wojny w ZSRR, tzw. „moskalami”, do których należał m. in. Matyas Rakosi a „krajowcami”, pochodzenia węgierskiego, działającymi podczas wojny na Węgrzech, w podziemiu, tj. János Kádár. T. Krawczyk, Stosunki między rządem i opozycją w wybranych państwach Europy, Toruń 2005, s. 194.

${ }^{5}$ Więcej na temat rewolucji 1956 roku patrz: V. Sebestyen, Twelve Days: The Story of the 1956 Hungarian Revolution, New York 2006; G. Litvan, J. M. Bak, L. H. Legters The Hungarian Revolution of 1956: reform, revolt and repression, 1953-1963, London 1996; P. Kecskemeti, The Unexpected Revolution: Social Forces in the Hungarian Uprising, Stanford 1961.

6 T. Krawczyk, op. cit., s, 194. Więcej na temat powstania 1956 roku zob. M. Horvath, 1956 Rozstrzelana Rewolucja. Walka Węgrów z Interwencja Sowieckq, Kraków 2006; V. Sebestyen, Dwanaście dni. Rewolucja Węgierska 1956, Warszawa 2006; Ch. Gati, Stracone złudzenia. Moskwa, Waszyngton i Budapeszt wobec powstania węgierskiego 1956 roku, Warszawa 2006; E. Czarkowska, op. cit.; G.Litvan (red.), Rewolucja węgierska 1956 roku. Reformy, bunt i represje 1953-1963, Warszawa 1996. 
i 70., które podnosiły poziom życia obywateli, zachowując przy tym główne założenia systemu socjalistycznego7.

W ramach liberalizacji życia politycznego w 1962 roku władze zezwoliły imigrantom politycznym z 1956 roku na powrót do kraju, a w marcu 1963 roku ogłosiły amnestię dla więźniów politycznych. W 1977 roku nastąpiła kolejna fala liberalizacji, tym razem $\mathrm{w}$ wymiarze kulturowym, polegająca na złagodzeniu cenzury i tolerowaniu przez państwo „wydawnictw drugiego obiegu"8. Liberalizację życia gospodarczego rozpoczął wprowadzony w 1968 r. program reform gospodarczych - Nowy Mechanizm Ekonomiczny - NEM, zakładający częściowe urynkowienie gospodarki. NEM w ciągu kilku lat odmienił strukturę społeczno-ekonomiczną i dał podstawy do formułowania się tzw. „drugiego społeczeństwa”. Zmiany te przejawiały się w powstaniu i funkcjonowaniu legalnego, prywatnego sektora gospodarki czy istnieniu szarej strefy obejmującej tzw. pracę po godzinach. W „drugą gospodarkę” zaangażowało się ponad 75\% społeczeństwa. Zmiany miały miejsce również $\mathrm{w}$ sektorze państwowym i objęły podział wielkich zakładów na mniejsze jednostki oraz zezwolenie na konkurencję między nimi ${ }^{9}$. W aspekcie liberalizacji życia politycznego przełomowe było uchwalenie w 1983 roku nowego prawa wyborczego. Nowa ordynacja dawała możliwość rywalizacji dwóch kandydatów (z partii komunistycznej) o jeden

7 M. Barański (red.), Systemy polityczne państw Europy Środkowej i Wschodniej. Ustrój, organy władzy, partie polityczne, Katowice 2005, s. 420 .

8 T. Krawczyk, op. cit., s. 230-231.

${ }^{9}$ P. Sula, System partyjny Republiki Węgierskiej, Wrocław 2005, s. 57. 
mandat. Dodatkowo społeczeństwo na spotkaniach wyborczych mogło dokonywać selekcji kandydatów (z partii komunistycznej). Wybory 1985 roku przeprowadzone według nowych zasad przyniosły liczne zmiany osobowe w składzie parlamentu, 63\% nowo wybranych polityków dostało się do parlamentu po raz pierwszy ${ }^{10}$.

Ten specyficzny program występujący na Węgrzech od początku lat 60. do drugiej połowy lat $80 .{ }^{11}$ zyskał miano „gulaszowego komunizmu” bądź wręcz „kadaryzmu”, gdyż był de facto oparty na rządach Kadara. Tolerował pluralizm ekonomiczny, opozycję w życiu politycznym w ograniczonym zakresie, stopniowo wprowadzał mechanizmy wolnorynkowe i poszerzał polityczną partycypację. Proces ten zmienił realny socjalizm na formy systemu mieszanego, łączącego paternalistyczną władzę z pozapolitycznymi wolnościami obywatelskimi. Władze z własnej woli rezygnowały z gospodarki centralnie planowanej, monopolu na środki masowego przekazu oraz ze stosowania przemocy politycznej. Liberalizacja polityczna i gospodarcza sprawiła, że kadaryzm nabrał częściowo cech charakterystycznych dla demokracji egalitarnej ${ }^{12}$.

10 Ibidem, s. 59.

11 Z przerwą w latach 1973-1975, kiedy w wyniku nacisków z Moskwy powrócono do zasad centralnego planowania, co zaowocowało kryzysem ekonomicznym na początku lat 80. Rok 1982 to próby przełamania kryzysu poprzez ponowne wprowadzenie pakietu ustaw liberalizacyjnych.

12 T. Krawczyk, op. cit., s. 230. Więcej na temat kadaryzmu patrz: A. Gerő, I. Pető, Unfinished socialism. Pictures from the Kadar era, bmw 1999. 
Przemiany gospodarcze niosły ze sobą wiele pozytywnych zjawisk. Prócz wykształcenia podstaw obywatelstwa ekonomicznego, sprzyjały rozwojowi przedsiębiorczości, zmianom w świadomości społecznej oraz doprowadziły do wykształcenia się klasy średniej w obowiązującym systemie. W aspekcie politycznym cechą odróżniającą Węgry od pozostałych państw bloku wschodniego była partycypacja inteligencji w działalności partyjnej. Podczas gdy w pozostałych państwach rok 1968 stanowił odwrót od zaangażowania w życie partii, o tyle na Węgrzech społeczeństwo wstępowało do partii „by mieć możliwość jej zmiany”13. Wśród minusów reform kadaryzmu niewątpliwie należy wymienić fakt, iż powstrzymały one rozwój społeczeństwa obywatelskiego, ruchów obywatelskich i opozycyjnych ${ }^{14}$.

Program ten sprawdzał się w warunkach węgierskich aż do połowy lat 80. Mimo że gospodarka Węgier funkcjonowała lepiej niż w innych państwach bloku radzieckiego i tutaj w drugiej połowie lat 80. pojawił się kryzys. Pod koniec lat 80. niewydolność systemu gospodarczego doprowadziła do „odrodzenia” społeczeństwa obywatelskiego i powstawania organizacji opozycyjnych. Sprzyjająca okazała się polityka nowego przywódcy ZSRR, Michaiła Gorbaczowa jak również coraz silniejszy ferment wewnątrz partii komunistycznej na Węgrzech. Janos Kadar, którego poglądy na tle zmian w Moskwie były za bardzo konserwatywne, tracił poparcie wśród

\footnotetext{
13 P. Sula, op. cit., s. 58.

14 Więcej na temat okresu kadarowskiego na Węgrzech zob.: B. Góralczyk, Węgierski pakiet, Warszawa 2000, s. 13-41.
} 
członków własnej partii oraz poparcie samego Gorbaczowa. W maju 1988 roku na skutek porozumienia frakcji reformatorów z frakcją centrum, Kadar był zmuszony ustąpić ze stanowiska sekretarza generalnego partii (pozostał tylko jej przewodniczącym, co nie gwarantowało mu nic prócz funkcji honorowych) 15 .

W latach 1987-1989 środowiska opozycyjne stworzyły podstawy niezależnych organizacji politycznych w kraju. Wśród organizacji opozycyjnych znajdowały się: Związek Wolnych Demokratów (SzDSz), Węgierskie Forum Demokratyczne (MDF), Związek Młodych Demokratów (FIDESZ). Ugrupowania te zyskały poparcie społeczeństwa, posiadały program antykomunistyczny jak również wystarczający potencjał polityczny ${ }^{16}$. Opozycja wobec systemu na Węgrzech

${ }^{15}$ M. Barański, op. cit., s. 421.

16 T. Krawczyk, op. cit., s. 198. Za jedną z pierwszych organizacji opozycji faktycznej można uznać Związek Młodych Demokratów (FIDESZ). Pierwszy zjazd miał miejsc w 1987 roku, a struktury organizacyjne powstawały od 30 marca 1988 roku, mając w założeniu stanowić alternatywę dla legalnego Związku Młodzieży Komunistycznej. W ramach FIDESZ działali głównie młodzi ekonomiści i prawnicy. Początkowo jako szeroki ruch społeczny, nie posiadał konkretnego programu. Późniejsze postulaty dotyczyły głównie wolności słowa oraz wprowadzenia demokracji i pluralizmu. Kolejną z organizacji był utworzony przez tzw. miejską inteligencję Związek Wolnych Demokratów (SzDSz). Grupował dawnych marksistów i semiopozycję rewizjonistyczną z lat 70. i 80. Występując w obronie praw człowieka z czasem ewoluował w kierunku liberalizmu demokratycznego, współpracując z narodowcami i ludowcami. Narodowcy i ludowcy z kolei skupili się wokół Węgierskiego Forum Demokratycznego (MDF), którego pierwsze regularne spotkania odbywały się od 1987 roku w miejscowości Lakitelek. MDF, skupiające literatów, ekonomistów i naukowców, głosiło początkowo program bardziej postępowy niż opozycyjny. Później ewaluował on w stronę 
miała jednak charakter specyficzny, gdyż stopniowo ewoluowała z „represyjnie tolerowanego” do „zinstytucjonalizowanego ruchu protestu” stricte politycznego. Wzrost aktywności i radykalizacja poglądów w większości tych ruchów nastąpiły dopiero w latach 1988-1989, czyli post factum, w momencie rozpoczęcia procesów demokratyzacji, w trakcie demontażu systemu realnego socjalizmu, gdy okazało się że wprowadzenie demokracji to tylko kwestia czasu ${ }^{17}$.

Prócz organizacji opozycji faktycznej na terenie Węgier działało wielu aktywistów opozycyjnych i ruchów semiopozycji. Charakterystyczna była działalność w ramach tzw. „antypolityki"18, rozumianej jako działalność kontrkulturowa, polegająca na tworzeniu niezależnych ruchów pokojowych, ekologicznych, naukowych, będących alternatywą dla władzy i polityki. Wyznawcy idei antypolityki nie popierali ani Związku Radzieckiego ani Zachodu ze Stanami Zjednoczonymi na czele, kładli nacisk na poszanowanie praw obywatelskich, postulo-

koncepcji „trzeciej drogi” między socjalizmem a komunizmem, aby później reprezentować idee chrześcijańskiej demokracji. 3 września 1988 MDF stało się oficjalnie organizacją stricte polityczną. Z ruchu tego wywodzą się późniejsi węgierscy politycy tj. Jozsef Antall i Peter Boross. Ugrupowaniem opozycyjnym o tradycjach historycznych była reaktywowana w listopadzie 1988 Niezależna Partia Drobnych Rolników. Wśród członków dominowali przedstawiciele starszego pokolenia, a partia zgodnie ze swoją tradycją programową stanowiła demokratyczna alternatywę komunizmu. T. Krawczyk, op. cit., s. 195-197.

${ }_{17}$ A. Wolff-Powęska, Oswojona rewolucja. Europa Środkowo-Wschodnia w procesie demokratyzacji, Poznań 1998, s. 286-289.

18 Pojęcie przypisywane Gyorgy Konradowi, węgierskiemu intelektualiście. W 1982 wydał on książkę „Antypolityka”, która została uznana za manifest programowy ruchów rewizjonistycznych młodzieżowych na Węgrzech. 
wali nie demokratyzację systemu, a całkowite zastąpienie struktur państwowych strukturami obywatelskimi ${ }^{19}$. Do semiopozycji zaliczały się również niezależne ruchy studenckie, mające na celu wspieranie i ochronę subkultury studenckiej, tj. koła naukowe, dyskusyjne, kluby polityczne, artystyczne, zapewniając swobodę poglądową, naukową oraz kulturalną. $\mathrm{Na}$ początku lat 80. powstała platforma porozumienia dla ruchów semiopozycyjnych „Sieć wolnych inicjatyw”, zajmująca się głównie drukiem i rozprowadzaniem nielegalnych czasopism $^{20}$.

Słabość i małą aktywność węgierskich ruchów antykomunistycznych można tłumaczyć na wiele sposobów. Pierwszym z powodów jest trauma obecna wśród węgierskiego społeczeństwa, spowodowana wydarzeniami 1956 roku. Istotniejszych przyczyn należy szukać we względnie dobrej sytuacji ekonomicznej panującej na Węgrzech oraz dużej autonomii społeczeństwa od władz, w porównaniu z pozostałymi państwami bloku radzieckiego. Węgierska opozycja, jako typowy ruch intelektualny, nie miała pola do wyrażania swoich poglądów. Nie odbywały się masowe wystąpienia robotników, ponieważ przedsiębiorstwa posiadały dużą niezależność finansową, na przykład same decydowały o poziomie płac

19 Myśl przewodnia wyznawców antypolityki wpłynęła na założenie i działalność pierwszego ruchu pokojowego na Węgrzech - Dialog. Początkowo członkowie Dialogu współpracowali ze Związkiem Młodzieży Komunistycznej i Krajową Radą Pokoju w demonstracjach pokojowych, głosząc prawo do życia w pokoju i pacyfistycznych kontaktów z innymi krajami Europy. Z racji deklarowanej niezależności od państwa Dialog został zdelegalizowany przez władze.

20 T. Krawczyk, op. cit., s. $232-236$. 
w danym zakładzie. Kościół katolicki i luterańsko-kalwiński również nie odgrywały znaczącej roli politycznej, ponieważ ponad 60 procent społeczeństwa deklarowało się jako niepraktykujące 21 .

Należy podkreślić, iż ruchy opozycyjne i semiopozycyjne wysuwały postulaty reformy systemu komunistycznego na Węgrzech, jednak nie negowały systemu w całości. Założenia kadaryzmu były częściowo zbieżne z celami większości ruchów opozycyjnych, a pod koniec lat 80. program opozycji niczym się nie różnił od programu reformistycznego skrzydła partii komunistycznej. Z tych powodów opozycja faktyczna pojawiła się w momencie demontażu systemu i była partnerem w dyskusji z komunistyczną elitą rządzącą 22.

Znaczącą rolę w procesie przemian ustrojowych na Węgrzech odegrała również (albo i przede wszystkim) Węgierska Socjalistyczna Partia Robotnicza, a konkretnie ewolucja wewnątrz partii, która stała się elementem sprzyjającym i w rezultacie przesądzającym o zmianie systemowej.

Pierwsze znamiona kryzysu i nadchodzących zmian w partii nastąpiły w 1986 roku i były związane ze słabnącym poparciem dla Kadara, który nie dostrzegał ani postępujących problemów gospodarczych ani zmian zachodzących w samym ZSRR, związanych z polityką „odwilży” Gorbaczowa. W rezultacie $\mathrm{w}$ WSPR nastąpił rozłam i podział na trzy frakcje we-

\footnotetext{
21 Więcej na temat działalności Kościoła Katolickiego na Węgrzech w czasach komunizmu zob. M. Koźmiński (red.), Odmiany i oblicza komunizmu. Węgrzy, Polacy i inni, Warszawa 2007, s. 91-130.

22 T. Krawczyk, op. cit., s. 241-242.
} 
wnętrzne: reformatorów, centrum oraz zwolenników utrzymania status quo i Kadara. Powyższy podział zainicjował Imre Pozsgay, rozpoczynając w grudniu 1986 narodową dyskusję dotyczącą reform. W rezultacie nowej polityki partii, w której coraz większe wpływy mieli reformatorzy, Kadar zrezygnował z pełnionej funkcji23.

Na Nadzwyczajnej Konferencji Partyjnej frakcja reformatorów postulowała zmiany systemowe, mające na celu wprowadzenie socjalistycznego pluralizmu. W rezultacie konferencji nastąpiły zmiany personalne w kierownictwie partii, w Komitecie Centralnym i Biurze Politycznym. Sekretarzem generalnym został Karol Grosz, powołano również cztery zespoły robocze mające na celu rozwiązać problemy społecznoekonomiczne ${ }^{24}$.

Jednym z pierwszych rozwiązań liberalizujących ustrój polityczny była ustawa z 11 stycznia 1989 roku. Parlament węgierski uchwalił ustawę o wolności zrzeszania się i demonstrowania swoich poglądów. Nie precyzowała ona wprawdzie zasad powstawania partii politycznych, ale również tego nie zakazywała, co de facto legalizowało ruchy opozycyjne i partie polityczne. Przełomowym momentem dla przemian wewnątrzpartyjnych, jak również dla całego systemu było posiedzenie KC WSPR w lutym 1989 roku, podczas którego podjęta została decyzja o pluralizacji życia społecznego i by ją urze-

\footnotetext{
23 P. Sula, op. cit., s. 59-61.

24 Pierwszy zespół miał zająć się podsumowaniem epoki kadarowskiej, drugi zespół kwestiami związanymi ze statutem partii, trzeci natomiast wypracować nowe sposoby komunikacji ze społeczeństwem.
} 
czywistnić - o wprowadzeniu systemu wielopartyjnego. Swoją dominującą rolę w partii przypieczętowali reformatorzy, deklarujący zasadę wyższości interesów społeczeństwa węgierskiego nad interesem aparatu partyjnego. Zmiany te zapoczątkowały dialog komunistów z opozycją, w postaci legalnych już partii i grup społecznych. Działania podjęte przez reformatorską frakcję partii komunistycznej prowadziły do liberalizacji systemu politycznego i oznaczały wejście na drogę ku demokracji parlamentarnej ${ }^{25}$. Można więc stwierdzić, iż demokratyzacja na Węgrzech miała charakter odgórny, gdyż to elity komunistyczne zdecydowały się na reformy systemowe.

Dzięki tym zmianom od początku 1989 roku na Węgrzech zaczął się kształtować system wielopartyjny, nie mający jeszcze jednak swojego odzwierciedlenia w parlamencie ${ }^{26}$.

Wśród nowo powstałych, legalnych partii opozycyjnych można wyodrębnić trzy grupy. Pierwszą z nich tworzą partie nowe, będące partiami protestu przeciw reżimowi węgierskiemu - były to partie w większości przypadków powstałe z wyżej wymienionych opozycyjnych ruchów społecznych. Zaliczają się do nich: Węgierskie Forum Demokratyczne (WFD), Związek Młodych Demokratów (FIDESZ), Związek Wolnych Demokratów (ZWD). Drugą grupę stanowiły partie historyczne, które po 1940 roku musiały zawiesić swoją działalność: Niezależna Partia Drobnych Rolników (NPDR), Chrześcijańsko-Demokratyczna Partia Ludowa (ChDPL), Węgierska

25 P. Sula, op. cit., s. 59-61.

${ }^{26}$ M. Migalski, op. cit., s. 56. 
Partia Socjaldemokratyczna (WPSd), Węgierska Partia Ludowa. W trzeciej grupie znalazły się partie będące odłamami skrzydła reformatorskiego partii komunistycznej, jak np. powstały w 1987 Nowy Front Marcowy²7.

Wielość nowych partii na arenie politycznej, a co za tym idzie wielość nurtów politycznych jakie reprezentowały rodziła potrzebę konsolidacji opozycji. W tym celu 22 marca 1989 roku zwołano pierwsze spotkanie grup kontestujących reżim. „Opozycyjny okrągły stół”, miał na celu wypracowanie wspólnego stanowiska opozycji wobec strony rządowej. W negocjacjach brali udział członkowie WFD, ZWD, FIDESZ, NPDR, Węgierskiej Partii Ludowej, WPSd, Niezależnej Demokratycznej Ligii Wolnych Związków Zawodowych ${ }^{28}$.

O pokojowej metodzie zmiany systemu zadecydowano 10 czerwca 1989 roku. 13 czerwca 1989 roku oficjalnie rozpoczęły się obrady tzw. trójkątnego stołu29. Trójkątnego gdyż strony negocjacji stanowili: partia komunistyczna, oficjalne organizacje społeczne - satelity WSPR oraz ugrupowania opozycyjne antykomunistyczne. $\mathrm{W}$ ramach prac powołano

\section{Ibidem, s. 57-59.}

28 Ibidem, s. 61.

${ }^{29}$ Niektórzy symbolicznie odczytują datę 13 czerwca. Obrady trójkątnego stołu rozpoczęły się ponad tydzień po wyborczym zwycięstwie Solidarności, 3 dni przed pogrzebem Imre Nagya (komunista, premier podczas rewolucji 1956 roku, ogłosił neutralność Węgier, stanął na czele oporu Węgrów przeciw interwencji radzieckiej, aresztowany i skazany na śmierć. Dla Węgrów symbol oporu antysowieckiego i antykomunistycznego). 6 lipca 1989 ogłoszono rehabilitację Nagya, w tym samym dniu zmarł János Kádár. J. Kochanowski, Wegry. Od ugody do ugody 1867-1990, Warszawa 1997, s. 186. 
6 komisji politycznych i 6 komisji ekonomicznych, wszystkie w składzie mieszanym (opozycyjno-rządowym). Do głównych kwestii podczas obrad należały następujące zagadnienia: zmiany konstytucyjne, projekty prawa o partiach, prawo wyborcze, zmiany prawa karnego, sprawy dotyczące mass mediów, reklamy, gwarancje pokojowej transformacji ${ }^{30}$.

Od transformacji w pozostałych krajach, proces ten odróżnia fakt, iż w rozmowach naprzeciw komunistom stanęło zorganizowane już społeczeństwo polityczne, czyli partie polityczne i organizacje społeczne, które istniały od 1988, a od czasu uchwalenia ustawy działały legalnie.

Znamienny był również fakt, iż w czasie, gdy w Warszawie czy Pradze negocjowano podczas obrad wyłącznie reguły okresu przejściowego, zasady jakimi miała się rządzić polityka do czasu wolnych wyborów, o tyle w Budapeszcie od razu tworzono reguły nowego demokratycznego państwa. Produktem węgierskiego Narodowego Okrągłego Stołu nie był kontrakt polityczny, ale projekty sześciu ustaw, które miały być fundamentalnymi regułami nowej demokratycznej polityki31.

Obrady narodowego trójkątnego stołu zakończyły się 18 września 1989 roku i dały początek procesowi demokratyzacji na Węgrzech. Na treść porozumień wpłynęła wyważona reakcja Związku Radzieckiego na wynik wyborów czerwco-

30 P. Sula, op. cit., s. 62.

31 A. Wołek, Demokracja nieformalna. Konstytucjonalizm i rzeczywiste reguły polityki w Europie Środkowej po 1989 roku, Warszawa 2004, s. 168 . 
wych w Polsce. Sukces trójkątnego stołu był jednak połowiczny, gdyż część opozycji - Związek Wolnych Demokratów oraz Związek Młodych Demokratów - odmówiły podpisania porozumień końcowych, nie popierając propozycji Węgierskiego Forum Demokratycznego i Węgierskiej Socjalistycznej Partii Robotniczej, dotyczącej wyboru prezydenta w powszechnym głosowaniu, ale poprzedzonym elekcją parlamentarną. Opozycja uznała powyższe rozwiązanie za korzystne tylko dla WSPR, gdyż gwarantowały partii zachowanie wpływów. Podejrzewano również układ Pozsgay - Antall - „wasz prezydent, nasz premier" na wzór Polski lub po prostu postulowano chęć całkowitego odcięcia się od komunizmu w myśl zasady „żadnej koalicji z komunistami” 32 .

Uzgodnienia przyjęto w postaci projektów ustaw dotyczących: poprawek do konstytucji, Trybunału Konstytucyjnego, partii politycznych, wyborów parlamentarnych, zmian w kodeksie karnym oraz zmian w postępowaniu karnym. Z powodu braku całkowitej zgodności do niektórych projektów dołączono rozwiązania alternatywne. $\mathrm{Na}$ drugą część porozumienia składały się zobowiązania sygnatariuszy, dotyczące zmian systemowych ${ }^{33}$. 23 października 1989 zmieniono nazwę państwa z Węgierskiej Republiki Ludowej na Republikę Węgierską.

Cechą charakterystyczną pierwszych wolnych wyborów, które odbyły się 25 marca 1990 roku, był fakt, iż rywalizacja rozegrała się między partiami reprezentującymi demo-

\footnotetext{
${ }^{32}$ P. Sula, op. cit., s. 63.

33 Ibidem, s. 63-64.
} 
kratyczną opozycję: Węgierskim Forum Demokratycznym a Związkiem Wolnych Demokratów. Ugrupowania postkomunistyczne nie odegrały znaczącej roli w wyborczej rywalizacji, mimo iż członkowie frakcji reformatorskich w partii odegrali kluczową rolę podczas pierwszego etapu przeobrażeń. W wyborach zwyciężyło Węgierskie Forum Demokratyczne uzyskując 42,5\% poparcia. Partia ta utworzyła koalicję z Niezależną Partią Drobnych Posiadaczy (11,4\%) i ChrześcijańskoDemokratyczną Partią Ludową (5,4\%). Szefem rządu został Jozef Antall ze zwycięskiej partii demokratycznej ${ }^{34}$.

Podsumowując, elementem wyróżniającym zmianę systemową na Węgrzech jest w pełni konsensualny charakter transformacji oraz zgodne przejście od komunizmu do systemu demokratycznego. Można również stwierdzić, iż dzięki temu komuniści zachowali kontrolę nad zachodzącymi procesami, równocześnie sami inicjując nowe reguły demokratyczne. Przypadek węgierskiej drogi odejścia od komunizmu cechuje zatem nie tylko konsensualność, ale również brak zerwania ciągłości między starym a nowym systemem 35 .

\footnotetext{
34 J. Wojnicki, Kształtowanie systemów wielopartyjnych Europy Środkowowschodniej 1989-2004, Pułtusk 2004, s. 47-49.

${ }^{35}$ A. Wołek, op. cit., s. 168-170.
} 